\title{
The Effect of Kinesiotape on Unilateral Sciatica
}

\author{
HEBA ALLAH E. MOHAMED, M.Sc.*; NADIA A. FYAZ, Ph.D.**; EBTESSAM F. GOMAA, Ph.D.** and \\ ESLAM A. TABEL, M.D.*** \\ The Department of Physical Therapy of Benha Fever Hospital, El-Qalubya*, Physical Therapy for Orthopedics, \\ Faculty of Physical Therapy, Cairo University** and Orthopedic Surgery, Faculty of Medicine, Benha University***, Egypt
}

\begin{abstract}
Background: Kinesio Taping is a therapeutic tool used for treatment of musculoskeletal disorders. However, there is little scientific evidence that describes its clinical efficacy.

Aim of Study: To investigate the effect of KT on radicular pain, sciatic nerve mobility, and functional disability in patients with unilateral sciatica.

Methods: This study was conducted from July 2017 to February 2018 on thirty patients ( 11 females, 19 males) with unilateral sciatica caused by lumbar disc herniation (LDH). Their age ranged from 30-40 years. All patients were referred by orthopedic surgeons who are responsible for diagnosis based on clinical and radiological examination. All patients were randomly allocated into 2 groups: Group (A) included 15 patients received Kinesio tape (KT) plus neural mobilization, group (B) included 15 patients received neural mobilization only, for 2 sessions per week for 3 weeks.
\end{abstract}

Methods: Visual Analogue Scale (VAS) was used to assess radicular pain. Universal goniometer was used to assess sciatic nerve mobility via range of motion of hip flexion testing. Oswestry disability questionnaire (ODI) was used to assess Functional status.

Results: Showed that both groups had improvement of the radicular pain $(p=0.001 *)$, sciatic nerve mobility ( $p$-value $=0.0001 *)$, and functional disability $(p$-value $=0.0001 *)$. To favor of KT group except in sciatic nerve mobility was insignificant between groups.

Conclusion: It can be concluded that KT added to neural mobilization are effective treatment for unilateral sciatica caused by lumbar disc herniation.

Key Words: Lumbar disc herniation (LDH) - Kinesio tape (KT) - Neural mobilization - Visual Analogue Scale (VAS) and Oswestry disability questionnaire (ODI).

\section{Introduction}

SCIATICA presents clinically as pain radiating into one or more lumbar or sacral dermatomes,

Correspondence to: Dr. Heba Allah E. Mohamed,

The Department of Physical Therapy of Benha Fever Hospital, El-Qalubya, Egypt being a symptom rather than a specific diagnosis. In approximately $90 \%$ of the cases, sciatica is caused by a herniated disc involving nerve root compression [1]. So it leads to pain, weakness, or numbness in a myotomal or dermatomal distribution [2]. The prevalence of symptomatic herniated discs has been estimated to be about $1-3 \%$. LDH is more common in persons aged 30-50 years old, with male predilection [3].

The natural course of lumbosacral radicular pain is favorable in $60 \%$ to $80 \%$ of patients and that the pain improves spontaneously or even disappears completely after 6 to 12 weeks [4]. Most of patients are treated conservatively in the first 6-12 weeks (acute and sub-acute phase) which is primarily aimed at pain reduction, either by analgesics or by reducing pressure on the nerve root in the form of physical therapy [5].

Kinesio Taping (KT) has become a very popular treatment for several health conditions over the last decade [6]. Chang et al., [7] conducted a systematic review about the effect of KT on patellofemoral pain syndrome. This study concluded that KT significantly improved muscle activity, motor function, and quality of life, benefits which were possibly facilitated by pain relief.

Kinesio taping is found to be effective in decreasing pain and muscular spasm, increasing the range of motion, improving local blood and lymphatic circulations, reducing edema, strengthen weakened muscles, control joint instability and postural alignment [8-10], providing cutaneous stimulation so it facilitates or limits movement [6], stimulating emotional warning for facilitating or preventing movement [11]. In addition, it is used for injury preventing rehabilitation and even performance enhancement [12]. Although some studies investigated the clinical effects of KT and reported 
that there were few high-quality studies and therefore insufficient evidence to support the use of this technique in clinical practice $[\mathbf{1 3 , 1 4}]$.

\section{Patients and Methods}

A randomized control trial study (parallel design) approved by the ethics committee of Physical Therapy College NO: P.T.REC/012/001658, Cairo University. All patients were recruited from Benha Teaching hospital, Benha Health Insurance Hospital, Benha Red Crescent hospital and Benha Fever hospital from July 2017 to February 2018, signed a consent form before participation, 30 patients diagnosed with unilateral lumbar disc herniation with sensory manifestation of both sexes (11 females and 19 males).

The patients were enrolled if the lumbar disc herniation at the L4-5 or L5-S1 levels [15]; grade II or III disc herniation with radicular sensory manifestation [16]. Age between 30-40 years to limit the possibility that the sciatica might have been complicated by arthritic changes [3,17]. Duration of symptoms from two weeks to three months with leg pain greater than back pain in a radicular distribution [5] . Body mass index (BMI) was less than $30 \mathrm{~kg} / \mathrm{m}^{2}$ [18]. Exclusion criteria were if $\mathrm{Pa}$ tients with red flags for a serious spinal condition. Treatment with epidural steroids or surgery, History of a major psychiatric or systemic illness [5]. Patients with motor manifestation, bilateral radiculopathy, Lumbar spondylosis or spondylolisthesis or with hip pathology, Allergic patients [6]

Subjects were randomly allocated by sealed envelope method into 2 groups: Group A $(n=15)$ received KT with Shacklock neural mobilization [19] for the sciatic nerve, while group B $(n=15)$ received Shacklock neural mobilization only. The treatment was 2 sessions per week for 3 weeks.

Outcome measures were pain (measured with VAS) [20], a Sciatic nerve mobility via range of motion of hip flexion testing (measured with universal goniometer) [21] and Functional status (measured with ODI) [22].

\section{Procedure:}

Visual Analogue Scale (VAS) in the radicular pattern:

The VAS is a tool for measuring musculoskeletal pain with excellent reliability and validity [23] Pain was recorded by the participant using a 10 $\mathrm{cm}$ VAS, where 0 represented no pain and 10 represented unbearable pain [20].

\section{Universal goniometer:}

Goniometric measurements of passive hip flexion during the straight leg raising (SLR) have been used as an indication of the mechanosensitivity of neural structures of the sciatic continuum [24].

The patient positioned on a plinth in the supine position. Test was performed without pillow under the patient's head [19]. The test performance needed two examiners. The first examiner stood beside the patient, maintaining the ankle in neutral and the foot in the vertical plane, raised the leg slowly and asked the patient to signal the onset of pain. Before measuring hip flexion range, the examiner ensured that the lumbar spine was in contact with the plinth. Then, the second examiner stood beside the patient, the examiner positioned the fulcrum of the goniometer over the greater trochanter of the femur; the stationary arm was placed parallel to the edge of the plinth and the moving arm was placed along the lateral midline of the thigh [21].

Oswestry disability questionnaire (ODI) (Appendix I):

The ODI remains a valid measure of conditionspecific disability [22]; the ODI has good reliability [25].

For each section of six statements of the questionnaire, the total score was 5. The final score calculated as follow:

(Total score/(5xnumbers of questions answered) x $100 \%$ [26].

The final ODI score ranged from 0 (no disability) to 100 (maximum disability). The original developers of the ODI intended for scores from 0 20 to indicate "minimal disability", 20-40 to indicate "moderate disability," 40-60 to indicate "severe disability", 60-80 to indicate "housebound", and 80-100 to indicate "bedbound" [27] .

\section{Treatment procedure:}

Allergy test:

All participants considered eligible for the study received a KT allergy test immediately after the initial assessment (but before randomization).

This test consisted of sticking a small piece $(1 \times 1 \mathrm{~cm})$ of KT on the volar side of forearm. The positive finding was redness or other skin changes would be noted in 15 minutes [28]. The patients who developed an allergic reaction to the tape would be asked to remove it immediately and would not be included in the study. After this allergic test, the allergy-free patients were be randomized to the treatment groups [29] 
Before appling KT, the treated area was cleaned and shaved [30]. In addition, the ends of KT used were rounded before application [31].

\section{KT application:}

KT is free of latex (ares-uncut www.aresports. com-Korea), with acrylic adhesive capacity, and activated by body heat, made of elastic polymer strand wrapped in cotton fibers $(100 \%)$ [32]. KT is designed to simulate the properties of human skin. It is as thick as epidermis and it may stretch 30$40 \%$ according to the resting length [33].

KT used in this study was waterproof, porous, and adhesive, with a width of $5 \mathrm{~cm}$ and thickness of $0.5 \mathrm{~mm}$. KT was applied in sitting position. Four I-strips was placed at $25 \%$ tension, overlapped in a star shape over the affected lumbar level. Strips were applied by pressing and adhering the central part before the ends [34] as in the Fig. (1).

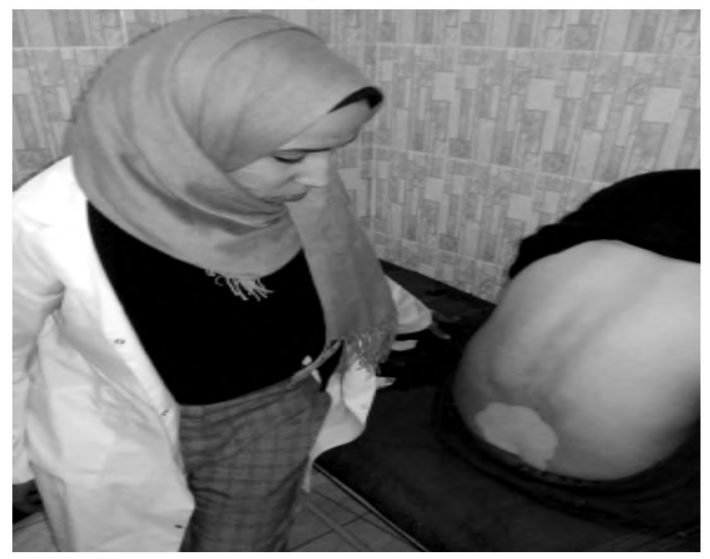

Fig. (1): KT technique.

\section{Neural mobilization:}

The patients received neural mobilization based on shacklock concept [19]. The treatment performance need an assistant.The average total treatment time will be approximately 30-40 minutes per session [35]

\section{First session:}

- Treatment of mechanical interface (reduced closing dysfunction):

Level (1): Static opener

Position: The patient waspositioned in contralateral side lying (affected side uppermost), the hips and knees were flexed to 90 degree and the patient was moved to the edge of the plinth so that their knees protruded a hand's breadth over the side of the bed.

- Progression 1: The patient was lying on the side with a bolster under the waist with their hips and knees flexed comfortably.
- Progression 2: The lower leg suspended over the side of the plinth while the other foot rested on the bed and hips and knees flexed to 90 degree.

- Progression 3: Both lower legs suspended over the side of the edge, so produced lateral flexion.

- Progression 4: The same as progression 3, but with additional bolster under the patients' waist.

Dosage: The patient asked to remain in each position for one minute for two sets. The maximum time for this maneuver was 5-15 minutes.

\section{- Treatment of distal sliding dysfunction:}

Level (1):

- Progression 1 (position away/move away):

Position: The patients laidwith their painful side uppermost, the hips and knees at $45^{\circ}$ flexion and the neck in neutral flexion/extension. The ipsilateral knee needed support in the form of a pillow so that it did not rest on the plinth and produce lumbar rotation.

\section{Mobilization: Passive neck flexion.}

- Progression 2 (position toward/move away):

Position: Side lying, painful side uppermost, the hip at approximately $45^{\circ}$ flexion and the ipsilateral knee straight.

\section{Movement: Passive neck flexion.}

Dosage: 20 repetitions in 4 sets with breaks of 10 seconds.

\section{Second session:}

- Treatment of mechanical interface (reduced closing dysfunction):

Level (1):

- Static opener: As described above.

- Dynamic opener:

Position: The patient positioned in contralateral side lying (affected side uppermost), the hips and knees were flexed to 90 degree and the patient was moved to the edge of the plinth so that their knees protruded a hand'sbreadth over the side of the bed.

Therapist'sposition: The therapist stood facing and leaned over the patient. The intention was to gently mobilize the patient's pelvis, alternated between opening and returning to the starting position. The therapist's proximal hand heldthe superolateral surface of the patient's ilium while the distal hand and forearm passed over the patient's buttock to cup over the ilium as well.

Movement: The therapist applied pressure in caudal direction on the patient's ilium making the 
pelvis rock over the downward greater trochanter. The therapist used their whole body from the feet upward to generate the movement. The mobilization was performed slowly and gently as reasonably wide amplitude movement.

Dosage: 10 repetitions.

- Treating distal sliding dysfunction:

Level (1): As prescribed before.

Level (2):

- Progression 1:

Position: Side lying, painful side uppermost and the neck flexed to its comfortable limits (position away).

Movement: Gentle ipsilateral straight leg raise to its maximum comfortable range (move toward).

\section{- Progression 2:}

Position: As prescribed in the above progression, except the neck was positioned in neutral flexion/extension.

Movement: Ipsilateral straight leg raise.

\section{- Progression 3:}

Position: The same, except neck position in extension to permit increased caudal sliding (position toward).

Movement: Unilateral straight leg raise (move toward).

Repetition: 20 repetitions in 4 sets with breaks of 10 seconds.

Third session:

- Treatment of mechanical interface:

Level (1):

- Static opener: As described above.

- Dynamic opener: As prescribed above, except 30 repetitions.

- Treatment of distal sliding dysfunction:

Level (1):

- Progression one: As described above.

- Progression two: As described above.

Level (2):

- Progression 1: As described above.

- Progression 2: As described above.

- Progression 3: As described above.

- Progression 4:

Position: The patient seated on the plinth as for slump test.
Movement: Cervical and thoracic extension, knee extension.

Repetition: 20 repetitions in 4 sets with breaks of 10 seconds.

\section{- Progression 5:}

Position: The patient was ipsilateral long sitting parallel with the plinth, short of symptoms.

Movement: Neck and thoracic extension to the end of the available range combined with knee extension and dorsiflexion to optimize caudal sliding.

Repetition: 20 repetitions in 4 sets with breaks of 10 seconds.

Forth session:

- Treatment of mechanical interface:

Level (1):

- Static opener: As described above.

- Dynamic opener: As prescribed before, except 50 repetitions.

- Treatment ofdistal sliding dysfunction:

Level (1): as described above.

Level (2): as described above.

Level (3a):

\section{- Progression 1:}

Patient position: Sitting over the side of the plinth in the slump position.

Movement: Passively neck extension with knee extension. The sensitizing movements were added, which were contralateral flexion of the spine, internal rotation and adduction of the hip. The hands guided the movement, felt for resistance and muscular behavior patterns and teaching the patient how to control the movement.

The technique of level 3 could produce some degree of resistance and muscular stretch symptoms.

Dosage: 20 repetitions in 4 sets with breaks of 10 seconds.

\section{- Progression 2.}

Position: Long sitting.

Movement: Neck extension with ipsilateral dorsiflexion, plus the sensitizing movements.

Dosage: 20 repetitions in 4 sets with breaks of 10 seconds.

Fifth session:

- Treatment of reduced closing dysfunction:

Level (1):

- Static opener: As described above. 
- Dynamic opener: As described above, except 50 repetitions.

Level (2): Dynamic closer:

- Progression 1: Dynamicmid-range closer.

Patient position: Patient was positioned in contralateral side lying, with hips and knees flexed to 90 , but this time with their legs on the bed.

Therapist position: The therapist leaned over the patient while placing the distal hand or forearm on the patient's buttock between the trochanter and ischial tuberosity. This was the key contact point at which the mobilization was initiated and controlled. The other hand palpated the segmental motion to verify that the movement produced by the mobilization was satisfactory.

The mobilization: Produced from the therapist's feet in which the key contact point was used to rock the pelvis in cephalic direction.

Dosage: 10 times.

- Progression 2: Dynamic end range closer.

Position: Contralateral side lying,hips and knees flexed to 90. The therapist faced cephalic, held the patient's feet with their distal hand underneath the patient's lower foot and applied pressure to the posterior surface of the patient's greater trochanter with their proximal hand. The ipsilateral flexion (closing) motion was achieved by the therapist moved the patient's feet around an axis that passedanteroposteriorlythrough the pelvis and moved the pelvis through application of pressure in a cephalic direction on the patient's buttock/greater trochanter.

Dosage: 10 oscillations.

- Treatment of caudal sliding dysfunction:

Level (1): As described above.

Level (2): As described above.

Level (3a): As described above.

Level (3b):

Position: Contralateral side lying, hips and knees flexed up to 90 , neck in neutral.

Movement: Start hip flexion, adduction, internal rotation, then knee extension then dorsiflexion.

Dosage: 20 repetitions in 4 sets with breaks of 10 seconds.

Level (3c):

- Progression 1:

Position: The patient laid with their painful side uppermost, the hips and knees at 45 degrees and the neck in neutral flexion/extension. Theipsilateral knee needed support in the form of pillow so that it did not rest on the plinth and produce lumbar rotation.

Movement: Active knee extension.

\section{- Progression 2:}

Position: The patient laid with their painful side uppermost, the hips and knees at 45 degrees and the neck in neutral flexion/extension. Theipsilateral knee needed support in the form of pillow so that it did not rest on the plinth and produce lumbar rotation.

Movement: Active knee extension and dorsiflexion.

\section{- Progression 2:}

Sixth session:

- Treatment of mechanical interface dysfunction: Level (1):

- Static opener: As described above.

- Dynamic opener: As described above.

Level (2):

- Dynamic closer: As described above.

- Treatment of caudal sliding dysfunction:

Level (1): As described above.

Level (2): As described above.

Level (3): As described above.

- Treatment ofreduced closing dysfunction with distal sliding dysfunction:

- First progression:

Position: The patient was positioned on their contralateral side (painful side uppermost); the hips and knees were flexed to 90 and supported on apillow.

Movement: The closing maneuverwas performed, while the patient performed knee extension actively.

- Second progression:

The same above, except active dorsiflexion was added.

Dosage: 5 oscillations.

\section{Results}

\section{General characteristics:}

As indicated by the independent $t$-test, there were no significant differences $(p>0.05)$ in the mean values of gender, age and BMI between both tested groups (Table 1). 


\section{Overall effect of hip flexion and ODI:}

The data were normally distributed for hip flexion and Oswestry disability questionnaire, as assessed by Shapiro-Wilk test ( $p>0.05$ ); accordingly, 2x2 mixed design MANOVA was used to compare the hip flexion and oswestry at different measuring periods at both groups.

Statistical analysis using $2 \times 2$ mixed design MANOVA indicated that there were significant effects of the tested group (the first independent variable) on the all tested dependent variables $(\mathrm{F}=4.374, p=0.023 *)$. Also, there were significant effects of the measuring periods (the second independent variable) on the tested dependent variables $(\mathrm{F}=124.901, p=0.0001 *)$. The interaction between the two independent variables was significant, which indicates that the effect of the tested group (first independent variable) on the dependant variables was influenced by the measuring periods (second independent variable) $\left(\mathrm{F}=3.466, p=0.046^{*}\right)$ (Table 2).

Table (1): Physical characteristics of participants in both groups (A\&B).

\begin{tabular}{|c|c|c|c|c|c|c|c|}
\hline \multirow{2}{*}{ Items } & \multicolumn{2}{|c|}{$\begin{array}{c}\text { Group A } \\
\text { Mean } \pm \text { SD }\end{array}$} & \multicolumn{2}{|c|}{$\begin{array}{c}\text { Group B } \\
\text { Mean } \pm \text { SD }\end{array}$} & \multicolumn{2}{|c|}{ Comparison } & \multirow{2}{*}{$S$} \\
\hline & Females & Males & Females & Males & $t$-value & $p$-value & \\
\hline \multirow[t]{2}{*}{ Gender } & $5(33.3 \%)$ & $10(66.7 \%)$ & $6(40 \%)$ & $9(60 \%)$ & & 0.705 & NS \\
\hline & \multicolumn{2}{|c|}{$15(100 \%)$} & \multicolumn{2}{|c|}{$15(100 \%)$} & & & \\
\hline Age (years) & \multicolumn{2}{|c|}{$33.4 \pm 3.04$} & \multicolumn{2}{|c|}{$33.93 \pm 3.15$} & -0.472 & 0.641 & NS \\
\hline BMI $\left(\mathrm{kg} / \mathrm{m}^{2}\right)$ & \multicolumn{2}{|c|}{$26.3 \pm 2.17$} & \multicolumn{2}{|c|}{$26.42 \pm 1.46$} & -0.177 & 0.861 & NS \\
\hline
\end{tabular}

Table (2): The 2x2 mixed design Multivariate Analysis of Variance (MANOVA) for all dependent variables at different measuring periods between both groups.

\begin{tabular}{lll}
\hline Source of Variation & F-value & $p$-value \\
\hline Groups & 4.374 & $0.023^{*}$ \\
Measuring periods & 124.901 & $0.0001^{*}$ \\
Interaction & 3.466 & $0.046^{*}$ \\
\hline
\end{tabular}

*Significant at alpha level $<0.05$.

\section{1- Hip flexion:}

Multiple pairwise comparison tests (Post hoc tests) revealed that there was significant increase of hip flexion at post treatment in compare to pretreatment ( $p$-value $=0.0001 *, \mathrm{~F}=156.291)$ in group A. While in group (B), the same test revealed that there was significant increase of hip flexion at post treatment in compare to pre-treatment ( $p$-value $\left.=0.0001^{*}, \mathrm{~F}=156.291\right)$ (Table 3, Fig. 2).

Multiple pairwise comparison tests (Post hoc tests) revealed that the mean values of the "pre" test between both groups showed no significant differences with ( $p=0.301, \mathrm{~F}=1.111)$. As well as, same tests revealed that there was no significant difference of the mean values of the "post" test between both groups with ( $p=0.05 \mathrm{~F}=4.206)$. In spite of there was no statistical significant difference between group A and group B, there was clinical difference and high percent of improvement in favor to group A.

\section{2- Oswestry disability questionnaire:}

Multiple pairwise comparison tests (Post hoc tests) in group A revealed that there was significant reduction of Oswestry disability questionnaire at post treatment in compare to pre-treatment ( $p$ value $=0.0001 *$, F-value $=233.469$ ). Also the same tests revealed that there was significant reduction of Oswestry disability questionnaire at post treatment in compare to pre-treatment $(p$-value $=$ $0.0001 *, \mathrm{~F}=233.469$ ). (Table 4, Fig. 3).

Multiple pairwise comparison tests (Post hoc tests) revealed that the mean values of the "pre" test between both groups showed no significant differences with $(p=0.274, \mathrm{~F}=1.245)$. However, same tests revealed that there was significant difference of the mean values of the "post" test between both groups with $(p=0.0001 *, \mathrm{~F}=16.924)$ and this significant improvement in favor to group A than group B.

The normality testing using Shapiro-Wilk test revealed that pain score were not normaly distributed so non parametric statistical tests in the form of Wilcoxon Signed Rank tests was used to compare 
VAS between pre and post treatment for each group and Mann-Whitney U-test was used to compare between both groups.

\section{Pain Level:}

In group A, "Wilcoxon Signed Rank test" revealed that there was significant decrease in pain level at post treatment in compare to pre treatment $(\mathrm{Z}=-3.461, p=0.001 *)$. Also the same test revealed that there was significant decrease in pain level at post treatment in compare to pre treatment $(\mathrm{Z}=$ 3.436, $p=0.001 *$ ). (Table 5, Fig. 4).

"Mann-Whitney test" revealed there was no significant difference between the both groups pre test $(\mathrm{U}=106.5, \mathrm{Z}=-0.256$, and $p=0.806)$. However the same test revealed that there was significant difference of the median values of the "post" treatment between both groups with $(U=50, Z=-2.758$, and $p=0.009 *)$ and this significant improvement in favor to group (A) than group (B).

Table (3): Mean $\pm \mathrm{SD}$ and $p$-values of hip flexion pre and post-test at both groups.

\begin{tabular}{lllllll}
\hline Hip flexion & \multicolumn{1}{c}{$\begin{array}{c}\text { Pre test } \\
\text { Mean } \pm \text { SD }\end{array}$} & $\begin{array}{c}\text { Post test } \\
\text { Mean } \pm \text { SD }\end{array}$ & MD & $\begin{array}{c}\% \text { of } \\
\text { change }\end{array}$ & $p$-value & F-value \\
\hline Group A & $47.78 \pm 12.17$ & $86.57 \pm 18.76$ & -38.78 & $81.16 \uparrow$ & $0.0001 *$ & 156.291 \\
Group B & $43.26 \pm 10.91$ & $74.26 \pm 13.25$ & -31 & $71.65 \uparrow$ & $0.0001 *$ & 156.291 \\
MD & 4.51 & 12.305 & & & \\
$p$-value & 0.301 & 0.05 & & & \\
F-value & 1.111 & 4.206 & & & \\
*Significant level is set at alpha level $<0.05$. & SD : Standard deviation. \\
MD: Mean difference. & & -value: Probability value.
\end{tabular}

Table (4): Mean \pm SD and $p$-values of Oswestry disability questionnaire pre and post-test at both groups.

\begin{tabular}{|c|c|c|c|c|c|c|}
\hline $\begin{array}{l}\text { Oswestry } \\
\text { disability } \\
\text { questionnaire }\end{array}$ & $\begin{array}{c}\text { Pre test } \\
\text { Mean } \pm \text { SD }\end{array}$ & $\begin{array}{c}\text { Post test } \\
\text { Mean } \pm \text { SD }\end{array}$ & MD & $\begin{array}{c}\% \text { of } \\
\text { change }\end{array}$ & F-value & $p$-value \\
\hline Group A & $52.44 \pm 10.29$ & $12.67 \pm 8.75$ & 38.15 & $72.7 \downarrow$ & 233.469 & $0.0001 *$ \\
\hline Group B & $55.5 \pm 13.30$ & $28.74 \pm 11.9$ & 26.76 & $48.21 \downarrow$ & 233.469 & $0.0001 *$ \\
\hline MD & -4.66 & -16.06 & & & & \\
\hline$p$-value & 1.245 & 16.924 & & & & \\
\hline F-value & 0.274 & $0.0001 *$ & & & & \\
\hline
\end{tabular}

Table (5): Median, $\mathrm{U}, \mathrm{Z}$, and $p$-values of pain level pre and post test at both groups.

\begin{tabular}{lllll}
\hline Pain level & $\begin{array}{c}\text { Pre test } \\
\text { Median }\end{array}$ & $\begin{array}{l}\text { Post test } \\
\text { Median }\end{array}$ & Z-value & $p$-value \\
\hline Group A & $7(2)$ & $0(1)^{* *}$ & -3.461 & $0.001^{*}$ \\
Group B & $7(3)$ & $2(2)$ & -3.436 & $0.001^{*}$ \\
U-value & 106.5 & 50 & & \\
$p$-value & & & & \\
\hline
\end{tabular}

*Significant level is set at alpha level $<0.05 . \quad p$-value: Probability value. ${ }^{* *}$ Median (Interquartile Range). 


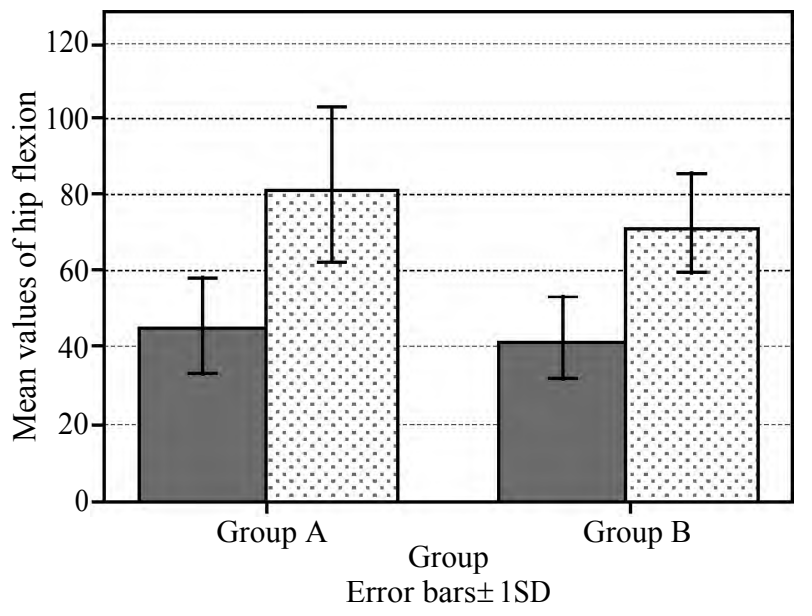

Pre-treatment $\because$ Post-treatment

Fig. (2): Mean values of hip flexion pre and post-tests in both groups.

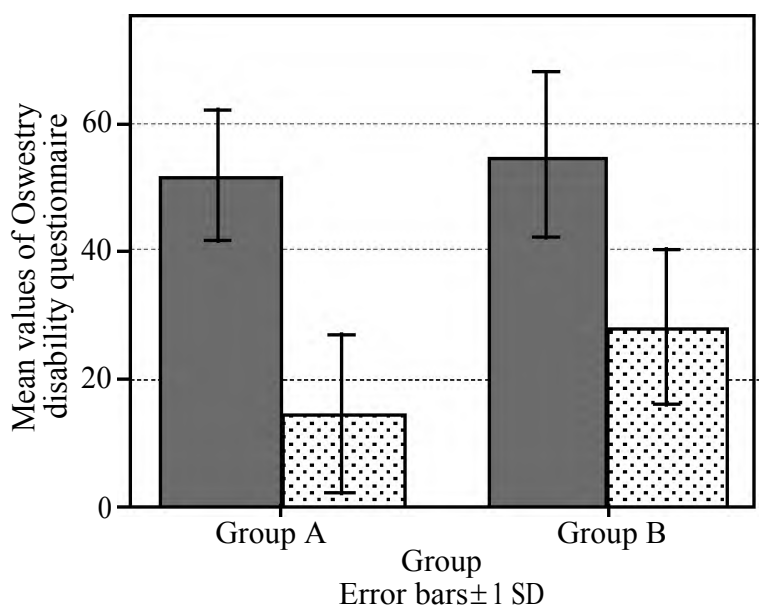

Pre-treatment $\because$ Post-treatment

Fig. (3): Mean values of Oswestry disability questionnaire pre and post-tests in both groups.

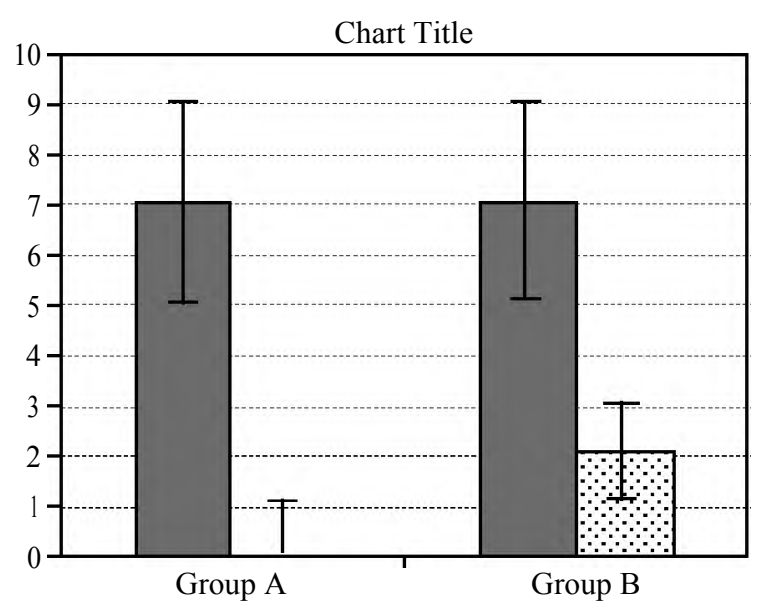

Pre-treatment $\theta$ Post-treatment

Fig. (4): Median values of pain level between both groups at different measuring periods.

\section{Discussion}

Lumbar disc herniation is common and often debilitating [36]. The efficacy of many conservative treatments for lumbar disc herniations with radiculopathy remains unclear [37]. Up to authors' knowledge there were no previous literature discussed the effect of KT on radicular pain, sciatic nerve mobility, functional disability in patients with unilateral sciatica caused by lumbar disc herniation.

In the present study, radicular pain, sciatic nerve mobility, and functional disability in patients with unilateral sciatica caused by disc herniation had a statistically significant improvement in both groups after receiving treatment. Radicular pain and functional disability had a statistically significant improvement in KT group rather than the other group. Sciatic nerve mobility was improved in both groups after treatment; however, there was no significant statistical difference in sciatic nerve mobility between the two groups.

The reasons for improvement in the current study could be explained as disc herniationassociated radiculopathy is both a biochemical and a mechanical disorder. A number of bioactive molecules known to be present in the nucleus pulposus, including interleukins and other inflammatory factors, have been purported to be biochemical "sensitizers" capable of making nerve roots susceptible to the mechanical effect of the herniated mass [38]. The exposure of the nerve root to nucleus pulposus material sensitizes the nerve root. The inflammatory changes around the neural structures cause them to become hypersensitive. In addition, injury to the disc causes it to lose height, allowing aberrant micro movements. These micro movements irritate sensory nerves, which result in back pain and radiating pain [39]

KT allows it to structurally lift the skin and opening up superficial lymphatic pathways of the affected area. KT also can provide a directional pull that guides the lymphatic fluid in the desired direction of drainage [40]. The increased space by $\mathrm{KT}$ is believed to reduce pressure by lifting the skin. In addition, KT acts as channels to direct the exudates to the nearest lymph duct [6]. KT increased somatosensory stimulation that can be used as proprioceptive input, so enhances the postural control system and facilitates the earlier return to activity [41]. In addition, KT activates the gate control mechanism and descending inhibitory mechanisms through sensory stimuli as well as decreases edema and inflammation and modulates 
superficial and deep fascia functions, so resulting in a decrease in pain [42].

Pain relief can consequently decrease disability levels [43]. This explains the greater improvement of the functional disability in KT group in this study. The improvement in functional disability could be illustrated by the effect of KT on pain reduction. This agrees with Keles et al., [44] who concluded that the KT improved pain level and disability in short-term and long-term and also reduced the analgesic need of the patients with lumbar disc herniation and the application of KT was for 3 weeks. In contrast to the current study, Velasco-Roldan et al., [45] concluded that KT had no immediate influence on pain sensitivity and lumbar mobility after a single application of KT over a 24-hour period in patients with mechanical low back pain. In addition, the use of different percentages of KT tension $(0 \%, 15-25 \%$, or $40 \%)$ did not seem to influence its impact on pain sensitivity and lumbar mobility.

The positive findings of the current study can be correlated indirectly with increased the circulation in the taped area. This agreed with Gramatikova, [46] who concluded that KT had faster and more significant reduction of the edema. They used the same tension of the present study, but the duration of KT application was shorter than the present study. In contrast, Yang and Lee, [47] and Stedge et al., [48] found that KT had no effect on circulation. These negative results of these 2 studies might have been as they conducted their studies on healthy people and the time of application of KT was very short.

The positive findings of the present study can also be correlated with the improvement of proprioception by KT. This agrees with Celenay and Kaya, [49] who concluded that KT had immediate improvement of postural stability and pain reduction in patients with chronic low back pain aged 20-65 years and the application of KT was for 45minutes. While Aytar et al., [50] concluded that KT had no effect on proprioception in patients with patellofemoral pain syndrome, with 50-75 KT tension, which was stretched more than the present study and the application of KT was shorter in duration.

Kelle et al., [51] concluded that KT with 25$30 \%$ tension added to minimal care had a significant greater reduction in disability and pain than minimal care only in patients with acute low back pain. The functional disability was also measured by ODI and the treatment period and the tension of KT were the same as our study. In contrast to Kamali et al., [52] who conducted a study on patients with chronic low back pain, KT was applied for 24 hours. They concluded that adding KT did not appear to improve the efficacy of manipulation to reduce pain and disability measured by ODI and increase the trunk muscle endurance in patients with chronic low back pain.

The small sample size, short follow-up period and the inability to blind participants and therapists are considered to be limitations of the current study.KT might has a positive psychological effect to the patients [12]. However any gain for pain reduction, postural alignment, or function as result of Kinesio taping was not told to the patients. The positive findings illustrated that KT had its effectson circulation and proprioception. However, the measurements for them were not considered. In addition, the positive findings can be correlated with natural resolution, however the majority of massive disc bulges shrinks over a period of 2 years [53]. To the authors' knowledge, it is the first study which investigates the effect on KT on unilateral sciatica caused by lumbar disc herniation. So, there was a lack of evidence about the efficacy of KT in these patients, it is better to add only-KT group in similar studies in future. In addition, this study demonstrated the effect of KT on the short term, and therefore, cannot make inferences relative to the long term effects.

\section{Conclusion:}

- Neural mobilization based on Shacklock concept is a successful treatment for improving the radiculopathy and functional disability in patients with unilateral sciatica caused by lumbar disc herniation.

- Adding KT with neural mobilization has a better effect on radiculopathy and functional disability than neural mobilization alone.

\section{Recommendations:}

- Further studies are needed with other measures on the effect of adding KT to neural mobilization for treatment of unilateral sciatica caused by lumbar disc herniation.

- Further studies are needed to evaluate the effect of $\mathrm{KT}$ alone.

- Further study should be performed with a larger sample size and long term follow-up. 


\section{References}

1- VALAT P., GENEVAY S., MARTY M., ROZENBERG S. and KOES B.: Sciatica. Best Pract Res. Clin. Rheumatol., 24: 241-252, 2010.

2- KREINER S., HWANG W., EASA E., RESNICK K., BAISDEN L., BESS S. and GHISELLI G.: An evidencebased clinical guideline for the diagnosis and treatment of lumbar disc herniation with radiculopathy. The Spine Journal, 14 (1): 180-191, 2014.

3- BONO M.: Lumbar Disc Herniation and Radiculopathy. In Principles of Orthopedic Practice for Primary Care Providers Springer, Cham, 37-46, 2018.

4- HOFSTEE J., GIJTENBEEK M. and HOOGLAND H.: Westside sciatica trial: Randomized controlled study of bed rest and physiotherapy for acute sciatica. J. Neurosurg, 96: 45-49, 2002.

5- AHMED N., TUFEL S., KHAN M. and KHAN P.: Effectiveness of neural mobilization in the management of sciatica. Journal of Musculoskeletal Research, 16 (03): 1350, 2013.

6- KASE K., WALLIS J. and KASE T.: Clinical therapeutic applications of the Kinesio Taping Method. 2 ed. Tokyo: Ken Ikai, 19-3 9, 2003.

7- CHANG D., CHEN C., LEE L., LIN Y. and LAI T.: Effects of Kinesio taping versus McConnell taping for patellofemoral pain syndrome: A systematic review and metaanalysis. Evidence-Based Complementary and Alternative Medicine, 2015.

8- SAYG1 K., AYDOSELI C., KABLAN N. and OFLUOG LU D.: The role of kinesio taping combined with botulinum toxin to reduce plantar flexors spasticity after stroke. Top Stroke. Rehabil., 17: 318-322, 2010.

9- KAYA E., ZINNUROGLU M. and TUGCU I. Kinesio taping compared to physical therapy modalities for the treatment of shoulder impingement syndrome. Clin. Rheumatol., 30: 201-207, 2011.

10- IGLESIAS J., PENAS F., CLELAND J., HU1JBREGTS P. and VEGA G.: Short term effects of cervical Kinesio Taping on pain and cervical range of motion in patients with acute whiplash injury: A randomized clinical trial. J. Orthop. Sports. Phys.Ther., 39: 515-521, 2009.

11- THELEN D., DAUBER A. and STONEMAN D.: The clinical efficacy of kinesio tape for shoulder pain: A randomized, double-blinded, clinical trial. J Orthop Sports PhysTher; 38 (7): 389-395, 2008.

12- POON Y, LI M, ROPER G, WONG M, WONG O, CHEUNG H (2015). Kinesiology tape does not facilitate muscle performance: A deceptive controlled trial. Manual. Therapy, 20 (1): 130-133, 2015.

13- MORRIS D., JONES D., RYAN H. and RYAN G.: The clinical effects of Kinesio ${ }^{\circledR}$ Tex taping: A systematic review. Physiotherapy Theory and Practice, 29 (4): 259270, 2013.

14- MOSTAFAVIFAR M., WERTZ J. and BORCHERS J.: A systematic review of the effectiveness of kinesio taping for musculoskeletal injury. The Physician and sportsmedicine, 40 (4): 33-40, 2012.

15- SIDDIQUE H., RAFIQUE Z., AHMAD N. and USMAN U.: Role of magnetic resonance imaging in lumbar spondylosis. J. Coll. Physician. Surg. Pak., 15: 396-9, 2005.
16-LURIE D., TOSTESON A. and TOSTESON D.: Reliability of magnetic resonance imaging readings for lumbar disc herniation in the spine patient outcomes research trial (SPORT). Spine, 33: 991-8, 2008.

17- ROTHSCHILD B.: Lumbar spondylosis. In: Emedicine publication. Available via WebMD. http://emedicine. medscape.com/article/249036-overview, 2008.

18- RIHN A., KURD M., HILIBRAND S., LURIE J., ZHAO W., ALBERT T., and WEINSTEIN J.: The influence of obesity on the outcome of treatment of lumbar disc herniation: Analysis of the Spine Patient Outcomes Research Trial (SPORT). The Journal of Bone and Joint Surgery. American Volume, 95 (1): 1, 2013.

19- SHACKLOCK M.: Clinical neurodynamics: a new system of musculoskeletal treatment. Elsevier Health Sciences, 2005.

20- HALSKI T., PTASZKOWSKI K., SIUPSKA L., PAPROCKA-BOROWICZ M., DYMAREK R., TARADAJ J. and ROSIN'CZUK J.: Short-term effects of kinesio taping and cross taping application in the treatment of latent upper trapezius trigger points: A prospective, singleblind, randomized, sham-controlled trial. Evidence-Based Complementary and Alternative Medicine, 2015.

21- SCHUBACK B., HOOPER J. and SALISBURY L.: A comparison of a self-stretch incorporating proprioceptive neuromuscular facilitation components and a therapistapplied PNF-technique on hamstring flexibility. Physiotherapy, 90 (3): 151-157, 2004.

22- JEREMY T., FAIRBANK and PAUL B.: The Oswestry disability index. Spine; 25 (22): 2940-2953, 2000.

23- BOONSTRA A., PREUPER S., RENEMAN M., et al.: Reliability and validity of the visual analogue scale for disability in patients with chronic musculoskeletal pain. Int. J. Rehabil. Res., 31: 165-169, 2008.

24- HALL T., ZUSMAN M. and ELVEY R.: Adverse mechanical tension in the nervous system? Analysis of the straight leg raise. Manual Ther; 3: 140-146, 1998.

25- SMEETS R., KÖKE A., LIN W., FERREIRA M. and DEMOULIN C.: Measures of function in low back pain/ disorders: Low Back Pain Rating Scale (LBPRS), Oswestry Disability Index (ODI), Progressive Isoinertial Lifting Evaluation (PILE), Quebec Back Pain Disability Scale (QBPDS), and Roland-Morris Disability Questionnaire (RDQ). Arthritis Care \& Research, 63 (S11): S158S173, 2011.

26- ADEL S.: Efficacy of neural mobilization in treatment of low back dysfunctions. Journal of American Science, 7 (4): 566-573, 2011.

27- FAIRBANK J., COUPER J., DAVIES J. and O'BRIEN J.: The Oswestry Low Back Pain Disability Questionnaire. Physiotherapy, 66: 271-3, 1980.

28- DJORDJEVIC O., VUKICEVIC D., KATUNAC L. and JOVIC S.: Mobilization with movement and kinesiotaping compared with a supervised exercise program for painful shoulder: Results of a clinical trial. Journal of Manipulative and Physiological Therapeutics, 35 (6): 454-463, 2012.

29- ADDED N., COSTA P., FUKUDA Y., FREITAS D., SALOMÃO C., MONTEIRO L. and COSTA L.: Efficacy of adding the kinesio taping method to guideline-endorsed conventional physiotherapy in patients with chronic 
nonspecific low back pain: A randomised controlled trial. BMC Musculoskeletal Disorders, 14 (1): 301, 2013.

30- DAWOOD R., KATTABEI O., NASEF S., BATTARJEE A. and ABDELRAOUF R.: Effectiveness of kinesio taping versus cervical traction on mechanical neck dysfunction. International Journal of Therapies and Rehabilitation Research, 2 (2): 1, 2013.

31- FIRTH L., DINGLEY P., DAVIES R., LEWIS S. and ALEXANDER M.: The effect of kinesiotape on function, pain, and motoneuronal excitability in healthy people and people with Achilles tendinopathy. Clinical Journal of Sport Medicine, 20 (6): 416-421, 2010.

32- ARTIOLI D. and BERTOLINI G.: Kinesio taping: Application and results on pain: Systematic review. Fisioterapia e Pesquisa, 21 (1): 94-99, 2014.

33- KAVLAK B., BAKAR Y. and SAR1 Z.: Investigation of the efficacy of different physiotherapy methods for neck pain. Journal of Musculoskeletal Pain, 20 (4): 284-291, 2012.

34- CASTRO-SÁNCHEZ A., LARA-PALOMO I., MATARÁN-PEÑARROCHA G., FERNÁNDEZ-SÁNCHEZ M., SÁNCHEZ-LABRACA N. and ARROYO-MORALES M.: Kinesio Taping reduces disability and pain slightly in chronic non-specific low back pain: A randomised trial. Journal of Physiotherapy, 58 (2): 89-95, 2012.

35- SARKARI E. and MULTANI K.: Efficacy of neural mobilisation in sciatica. Journal of Exercise Science and Physiotherapy, 3 (2): 136, 2007.

36- BJORNSDOTTIR G., BENONISDOTTIR S., SVEINBJORNSSON G., STYRKARSDOTTIRU., THORLEIFSSON G., WALTERS B. and HANSDOTTIR R.: Sequence variant at $8 \mathrm{q} 24.21$ associates with sciatica caused by lumbar disc herniation. Nature Communications, 8 : 14265, 2017.

37- RHEE M., SCHAUFELE M., and ABDU A.: Radiculopathy and the herniated lumbar disc: Controversies regarding pathophysiology and management. JBJS, 88 (9): 20692080, 2006.

38- MIYAMOTO H., SAURA R., DOITA M., KUROSAKA M. and MIZUNO K.: The role of cyclooxygenase- 2 in lumbar disc herniation. Spine, 27: 2477-83, 2002.

39- MCGILL M.: Low Back Disorders, 3E. Human Kinetics; Canada: 1-404, 2015.

40- STOCKHEIMER R.: Kinesio taping and lymphoedema. Advance Healing, 3: 22-23, 2006.

41- HALSETH T., McCHESNEY W., DEBELISO M., VAUGHN R. and LIEN J.: The effects of kinesioTM taping on proprioception at the ankle. Journal of Sports Science \& Medicine, 3 (1): 1, 2004.

42- AZATCAM G., ATALAY S., AKKAYA N., SAHIN F., AKSOY S., ZINCIR O. and TOPUZ O.: Comparison of effectiveness of Transcutaneous Electrical Nerve Stimu- lation and Kinesio Taping added to exercises in patients with myofascial pain syndrome. Journal of back and musculoskeletal rehabilitation, 30 (2): 291-298, 2017.

43- BIALOSKY E., BISHOP D., PRICE D., ROBINSON E. and GEORGE Z.: "The mechanisms of manual therapy in the treatment of musculoskeletal pain: A comprehensive model." Manual Therapy, 14 (5): 531-538, 2009.

44- KELES Y., YALCINKAYA Y., GUNDUZ B., BARDAK N., ERHAN B.: Kinesio Taping in patients with lumbar disc herniation: A randomised, controlled, double-blind study. Journal of Back and Musculoskeletal Rehabilitation, 30 (3): 543-550, 2017.

45- VELASCO-ROLDÁN O., RIQUELME I., FERRAGUTGARCÍAS A., HEREDIA-RIZO M., RODRÍGUEZBLANCO C. and OLIVA-PASCUAL-VACA Á.: Immediate and Short-Term Effects of Kinesio Taping Tightness in Mechanical Low Back Pain: A Randomized Controlled Trial. PM. \& R., 2017.

46- GRAMATIKOVA M.: Kinesio-taping effect on edema of knee joint. International Journal of Kinesiology and Other Related Sciences 'Research in Kinesiology, 43 (2): 220223, 2015.

47- Yang M. and Lee H.: Is Kinesio Taping to Generate Skin Convolutions Effective for Increasing Local Blood Circulation? Medical Science Monitor, 24: 288-293, 2018.

48- Stedge L., Kroskie M. and Docherty L.: Kinesio taping and the circulation and endurance ratio of the gastrocnemius muscle. Journal of Athletic Training, 47 (6): 635 642, 2012

49- CELENAY T. and KAYA O.: Immediate effects of kinesio taping on pain and postural stability in patients with chronic low back pain. Journal of Bodywork and Movement Therapies, 1-21, 2017.

50- AYTAR A., OZUNLU N., SURENKOK O., BALTAC 1 G, OZTOP P. and KARATAS M.: Initial effects of kinesio ${ }^{\circledR}$ taping in patients with patellofemoral pain syndrome: A randomized, double-blind study. Isokinetics and Exercise Science, 19 (2): 135-142, 2011.

51- KELLE B., GÜZEL R. and SAKALL1 H.: The effect of Kinesio taping application for acute non-specific low back pain: A randomized controlled clinical trial. Clinical Rehabilitation, 30 (10): 997-1003, 2016.

52- KAMALI F., SINAEI E. and TAHERKHANI E.: Comparing spinal manipulation with and without Kinesio Taping ${ }^{\circledR}$ in the treatment of chronic low back pain. Journal of Bodywork and Movement Therapies, 2017.

53- BENSON T., TAVARES P., ROBERTSON C., SHARP R., and MARSHALL W.: Conservatively treated massive prolapsed discs: A 7-year follow-up. Annals of the Royal College of Surgeons of England, 92: 147-153, 2010.

54- ALGARNI A., GHORBEL S., JONES J. and GUERMAZI M.: Validation of an Arabic version of the Oswestry index in Saudi Arabia. Annals of physical and Rehabilitation Medicine, 57 (9): 653-663, 2014. 


\section{Appendix I}

Oswestry disability questionnaire: (Jeremy et al., 22).

Please answer every section. Mark one box only in each section that most closely describes you today.

In the past week, please tell us how pain has affected your ability to perform the following activities.

(Circle the one statement that best describes your average ability).

Please read:This Questionnaire It is designed to enable us to understand how much your low back pain has affected your ability to manage your everyday activities.

Section 1-Pain intensity:

0 - I have no pain at the moment.

1 - The pain is very mild at the moment.

2- The pain is moderate at the moment.

3 - The pain is fairly severe at the moment.

4- The pain is very severe at the moment.

5- The pain is the worst imaginable at the moment.

Section 2- Personal care (washing, dressing, etc.):

0 - I can look after myself normally without causing extra pain.

1 - I can look after myself normally but it is very painful.

2- It is painful to look after myself and I am slow and careful.

3- I need some help but manage most of my personal care.

4- I need help every day in most aspects of selfcare.

5- I do not get dressed, wash with difficulty and stay in bed.

\section{Section 3-Lifting:}

0 - I can lift heavy weights without extra pain.

1- I can lift heavy weights but it gives extra pain.

2- Pain prevents me from lifting heavy weights off the floor but I can manage if they are conveniently positioned, e.g. on a table.

3- Pain prevents me from lifting heavy weights but I can manage light to medium weights if they are conveniently positioned.

4- I can lift only very light weights.

5- I cannot lift or carry anything at all.

\section{Section 4-Walking:}

0 - Pain does not prevent me walking any distance.

1- Pain prevents me walking more than 1 mile.

2- Pain prevents me walking more than than $1 / 2$ of a mile.

3- Pain prevents me walking more than 100 yards.

4- I can only walk using a stick or crutches.

5- I am in bed most of the time and have to crawl to the toilet.

\section{Section 5-Sitting:}

0 - I can sit in any chair as long as I like.

1- I can sit in my favourite chair as long as I like.

2- Pain prevents me from sitting for more than 1 hour.

3- Pain prevents me from sitting for more than $1 / 2$ an hour.

4- Pain prevents me from sitting for more than 10 minutes.

5- Pain prevents me from sitting at all.

\section{Section 6-Standing:}

0 - I can stand as long as I want without extra pain.

1- I can stand as long as I want but it gives me extra pain.

2- Pain prevents me from standing for more than 1 hour.

3- Pain prevents me from standing for more than $1 / 2$ an hour.

4- Pain prevents me from standing for more than 10 minutes.

5- Pain prevents me from standing at all.

Section 7-Sleeping:

0 - My sleep is never disturbed by pain.

1- My sleep is occasionally disturbed by pain.

2- Because of pain I have less than 6 hours sleep.

3- Because of pain I have less than 4 hours sleep.

4- Because of pain I have less than 2 hours sleep.

5- Pain prevents me from sleeping at all.

Section 8-Sex life (if applicable):

0 - My sex life is normal and causes no extra pain.

1- My sex life is normal but causes some extra pain.

2- My sex life is nearly normal but is very painful.

3- My sex life is severely restricted by pain. 
4- My sex life is nearly absent because of pain.

5- Pain prevents any sex life at all.

\section{Section 9-Social life:}

0 - My social life is normal and causes me no extra pain.

1- My social life is normal but increases the degree of pain.

2- Pain has no significant effect on my social life apart from limiting my more energetic interests, e.g. sport, etc.

3- Pain has restricted my social life and I do not go out as often.
4- Pain has restricted social life to my home.

5- I have no social life because of pain.

\section{Section 10-Travelling:}

0 - I can travel anywhere without pain.

1- I can travel anywhere but it gives extra pain.

2- Pain is bad but I manage journeys over two hours.

3- Pain restricts me to journeys of less than one hour.

4- Pain restricts me to short necessary journeys under 30 minutes.

5- Pain prevents me from travelling except to receive treatment.

The Arabic version ofOswestry disability questionnaire: (Algarni et al., 54).

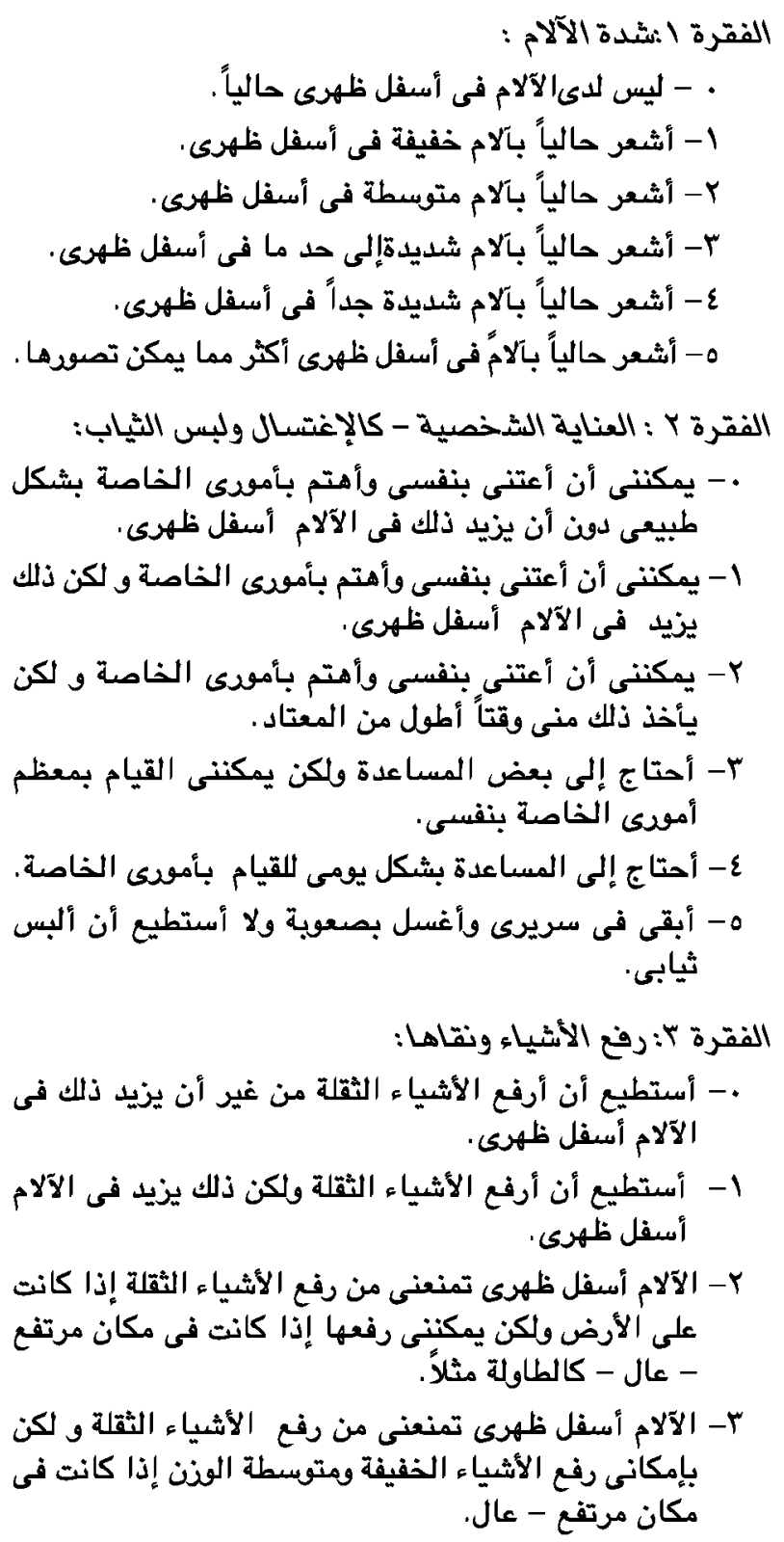$$
\text { الفقرة انشيدة الآلام : }
$$

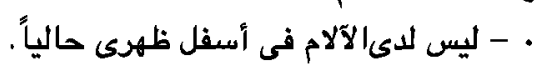

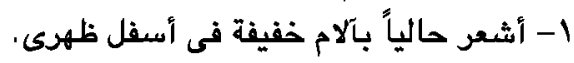

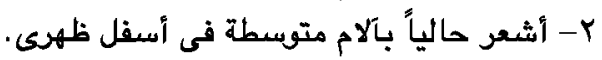

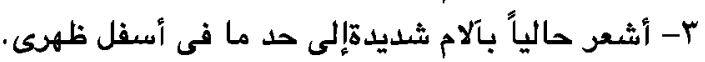

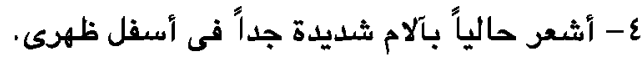

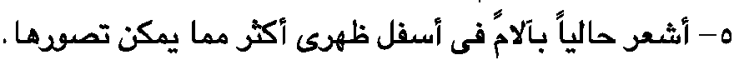$$
\text { الفقرة ץ : العناية الثخصية - كالإغتسال ولبس الثياب: }
$$

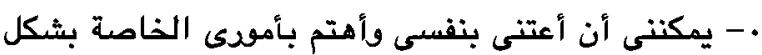

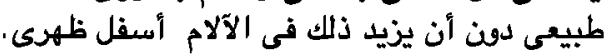

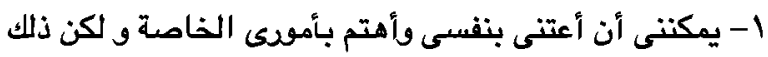$$
\text { يزيد في الآلام أسفل ظهرىى. }
$$

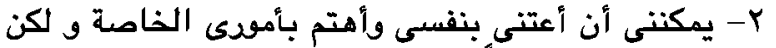

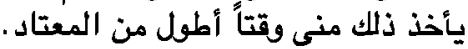

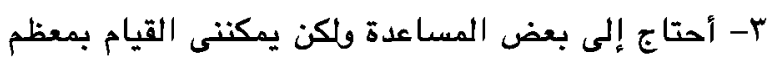

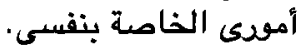$$
\text { ع- أحتاج إلى المساعدة بشكل يومى للقيام بأمودى الخاصة. }
$$

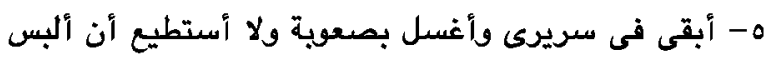$$
\text { ثيابى. - مئ في }
$$$$
\text { الفقرة بّ: رفع الأشُياء ونقاهـا: }
$$$$
\text { •- أستطيع أن أرفع الأشياء الثقلة من غير أن يزيد ذألك فى الثماء }
$$

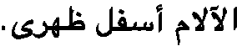$$
\text { 1- أستطيع أن أرفع الأشياء الثقلة ولكن ذلك يزيد فى الآلام }
$$

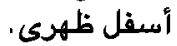$$
\text { Y- الآلام أسفل ظهرى تمنعنى من رفع الأشياء الثقلة إذا كانت }
$$

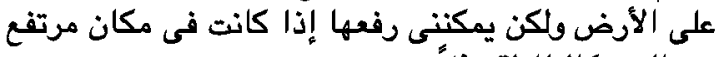

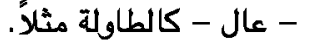

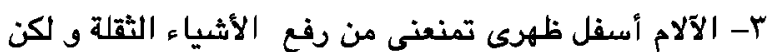

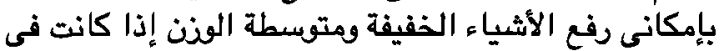$$
\text { مكان مرتفع - عال. }
$$ 
r- الآلام أسفل ظهرى تمنعنى من الوقوف لأكثر من نصف ع- الآلام أسفل ظهرى تمنعنى من الوقوف لاكثر من ـادقائق. ه- الآلام أسفل ظهرى تمنعنى من الوقوف مط الوالقاً .

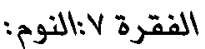

•- نومى لا يضطرب أبداً بسبب الآلام أسفل ظهرى الون.

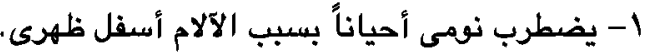

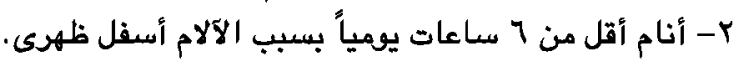

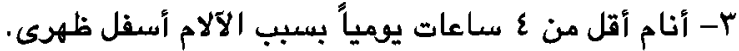

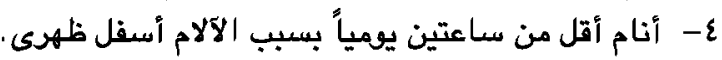
0 - لا أستطيع النوم مطلقاً بسبب الآلام أسفل ظهري الامي.

الفقرة 1 : الحياة الجنسية (هذه الفقرة للمتزوجين أو من سبق الهبق

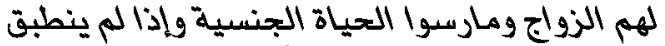

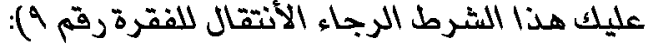
•- حياتى الجنسية عادية ولا تسبب زيادة في الآلام أسفل ظهرى. 1- حياتى الجنسية عادية ولكنها تسبب زيادة فى بعض الآلام أسفل ظظهرى. r- حياتى الجنسية تكاد تكون عادية ولكنها تسبب لى آلاما شديدة في أسفل ظهرىى. r- عياتى الجنسية نادرة جداً بسبب الآلام أسفل ظهرىى.

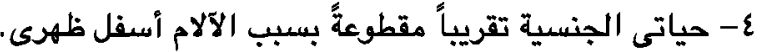
ه- الآلام أسفل ظهرى تمنعنى من الحياة الجنسية الجنية مطلقاً. 1- لم يسبق لى الزواج ولم أمارس الحياة الجنسية
الفقرة 4: الحياة الأجتماعية (زيارة وآستقبال الأقارب

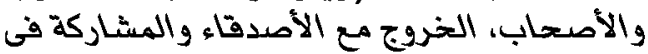
الأحتفالات أو الأنشُطة الأجتماعية.....).

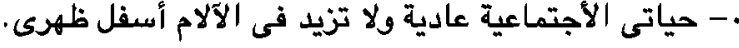
1- حياتى الأجتماعية عادية ولكنها تزيد من حدة الآلآلام أسفل الآل

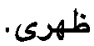
Y- الآلام أسفل ظهرى لا تؤثَّ على حياتى الإجتماعية ولكنها تقلل من أعمالى التى تتطلب مجهود الَاً كبيراً.

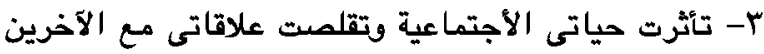
بعبب الآلام أسفل ظهرى. ع- بسبب الآلام أسفل ظهرى أصبحى فئ حياتى الأجتماعية منحصرة في المنزل.

0- حياتى الاجتماعية أنقطعت بسبب الآلام أسفل ظهرى. الفقرة -1: السفر: - أستطيع السفر إلى أى مكان من غير أن يزيد ذلك فى الآلام

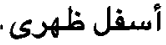
1- أستطيع السفر إلى أى مكان ولكنه يزيد في الآلام أسفل ظלهرى r- الآلام أسفل ظهرى شديدة ولكنى أستطيع تحمل السفر فى حدود الساعتين. r- الآلام أسفل ظهرى تقيد رحلاتى (سفرى) لأقل من ساعة.

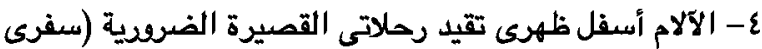
القصير) لأقل من نصف ساعة فئ رهاتي.

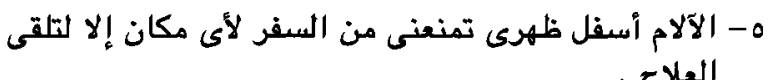
1- 1 لم أسافر يوماً ما (لم أفعل ذلك).

\section{تأثير شريط الكينيسيو على عرق النسا الأحادى الجانب}

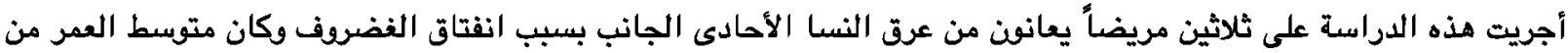

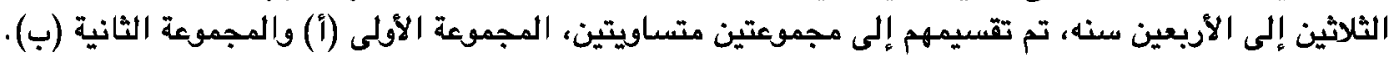

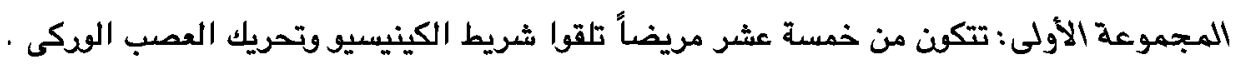

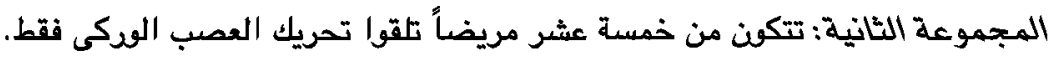
طريقة القياس: تم تقييم شدة الألم عن طريق المقياس التناظرى البصرى، و تقييم مدى حركة الثنى الوركى عن طريق مقياس

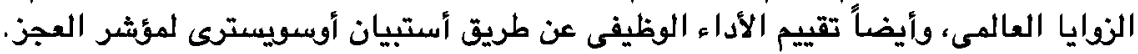

أظهرت النتائج وجود تحسن فى المجموعتين الأولى والثانية وبالأخص، الأولى حيث أن أضافة شريط الكينيسيو أوجدت نتائج أفضل من تحريك العصب الوركى بمفرده. الأستنتاج:

- كلا من العلاج بتطبيق تحريك العصب الوكى لعرق النسا الأحادى الجانب أو أضافة شريط الكينيسيو لتحريك العصب الوكى العي

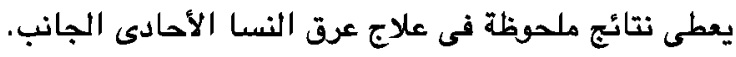

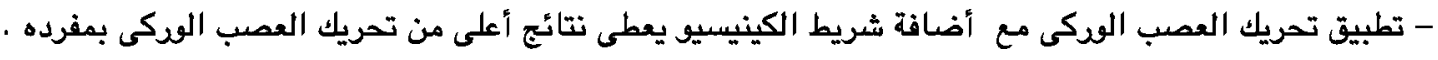

